\title{
Prevalence of Bovine Trypanosomosis in Dembecha Woreda Amhara Region, Northwest Ethiopia
}

Demelash Mekonnen, Amare Eshetu and Tesfaheywet Zeryehun*

College of Veterinary Medicine, Haramaya University, PO Box 301, Dire Dawa, Ethiopia

\begin{abstract}
This study was conducted in Dembecha Woreda of Amhara region, Northwest Ethiopia. The study was carried out on 384 indigenous cattle kept in mixed crop-livestock production system to estimate the prevalence of bovine trypanosomosis and associated risk factors. The study employed parasitological survey (buffy coat examination) and hematological study (packed cell volume [PCV] and thin blood smear). In the present study, the overall prevalence of trypanosomosis was $8.6 \%$ (33/384). Trypanosoma congolense (54.54\%) and Trypanosome vivax (45.45\%) were the only two species of Trypanosomas encountered in the study area. Among the risk factors, sex and age were found to have no significant association with the prevalence of trypanosomosis $(p>0.05)$, but body condition and coat color of animals were found to have a significant association $(p<0.05)$ with prevalence of trypanosomosis in the studied animals. In this study infected animals were with mean PCV value of $22.94 \pm 2.70 \%$ which is significantly lower $(p<0.05)$ than that of the non-infected animals $(27.24 \pm 5.02 \%)$. The study concluded that Trypanosomosis being an economically important disease in cattle the $8.6 \%$ prevalence entail that more attention should be given to be adapting on integrated disease control strategy including the vector as well as the parasites.
\end{abstract}

Keywords: Cattle; Packed cell volume; Trypanosoma congolense; Trypanosoma vivax; Dembecha district

\section{Introduction}

Trypanosomosis is an economically important disease of domestic animals in many part of the world particularly in sub Saharan Africa $[1,2]$. The disease is among factors that limit the expected outcome from animal production in tropical Africa.

In countries like Ethiopia trypanosomosis is among the major setback to cattle production with direct and indirect economic loss. It is a serious constraint to agricultural production in extensive area of the tsetse infested Ethiopian low land [3]. It's highly prevalent in most arable and fertile land South West and North West part of the country. In Ethiopia an aggregated annual economic losses from animal death through direct mortality and reduced productivity and reproductive performance where estimated at 150 million US dollars [4].

Bovine trypanosomosis is a parasitic disease caused by protozoan parasite in the genus Trypanosoma [3]. They are obligatory parasites which are microscopic, elongated, unicellular, usually having two hosts, the invertebrate and vertebrate hosts. The three most important Trypanosomas species affecting cattle are Trypanosoma vivax (sub genus duttenelle); $T$. congelense (sub genus nannomonas) and $T$. brucie (sub genus trypanozoon). The problem of Africa animal trypanosomosis is associated with the disease with the presence of tsetse flies [5]. The disease is mostly associated with the occurrence of tsetse fly between $14^{\circ} \mathrm{N}$ and $29^{\circ}$ South. T. vivax is the only species of tsetse transmitted Trypanosomas established in area free of tsetse flies [6]. Tsetse flies inhibit wide range of habitats in African continent including Ethiopia. Currently a wide area of the country is infested with tsetse flies including Glossina tachinoides, Glossina pallidip, Glossina morsitans and Glossina longipennis [7].

Trypanosomosis is argued to be the single most important constraints to animal agriculture in the sub humid and non-forested portion of humid zone of Africa. The disease has caused direct and indirect economic impact on livestock production. The indirect impact is related to the opportunity cost of land and other resources currently not used for livestock production owning prevention and control strategies of tsetse flies. The annual losses in meat production alone with estimated at 5 billion US dollars [8]. Economic losses due to trypanosomosis are estimated 2 billion US dollars per year. Approximately $30 \%$ of the 150 million cattle in the life are at risk of the infection. Thus, if control of trypanosomosis could be achieved there could be potential even at the current low rate of production to increase meat supply of continent by the approximately $16 \%$ and milk supply by $17 \%$ of current production level [9].

In West Gojjam Zone of Amhara regional state trypanosomiasis is among the most important disease of cattle [10-12]. But little has been done with regard to systematic investigation of the diseases and the associated risk factors in this area. The study aims to estimate the prevalence of bovine trypanosomosis in Dembecha Woreda of West Gojjam Zone in Amhara regional state, North West Ethiopia.

\section{Materials and Methods}

\section{Study area}

The current study was carried out in Dembecha Woreda of Gojjam Zone in Amhara Regional State, North-western Ethiopia. It is located about $370 \mathrm{~km}$ North West of the capital of Ethiopia, Addis Ababa, and $220 \mathrm{~km}$ South East of Bahair Dar, the capital of Amhara region. West Gojjam zone is located at $10^{\circ} 30^{\prime}$ North, Latitude and $37^{\circ} 29^{\prime}$ East longitude [12]. The climate alternate with long summer rainfall

*Corresponding author: Tesfaheywet Zeryehun, College of Veterinary Medicine, Haramaya University, PO Box 301, Dire Dawa, Ethiopia, Tel: +251255530084; E-mail: tesfahiwotzerihun@yahoo.com

Received December 28, 2016; Accepted January 16, 2017; Published January 17, 2017

Citation: Mekonnen D, Eshetu A, Zeryehun T (2017) Prevalence of Bovine Trypanosomosis in Dembecha Woreda Amhara Region, Northwest Ethiopia. J Vet Sci Technol 8: 413. doi: 10.4172/2157-7579.1000413

Copyright: (c) 2017 Mekonnen D, et al. This is an open-access article distributed under the terms of the Creative Commons Attribution License, which permits unrestricted use, distribution, and reproduction in any medium, provided the original author and source are credited. 
between June-September and winter dry season between DecemberMarch with a mean annual rainfall 1200-1600 mm. The mean temperature of the study area is between $10-20^{\circ} \mathrm{C}$ and altitude ranges from 1400-2300 m.a.s.l. The mean agricultural activities currently practice includes irrigation (modern to traditional), animal production and crop production (mixed farming) activities holds $90 \%$ of the total agricultural activities. The major agricultural production seasonally harvested includes sorgum, wheat, teff, maize and other legume groups [13].

\section{Study design, study population and sample size determination}

The study was carried out on 384 local indigenous Zebu which are kept under mixed farming system. The study was conducted to assess the status of vector born trypanosomosis in each district of the Dembecha Woreda. Animals were selected from the study population using simple random sampling technique and purposive sampling was the method followed to select the two study peasant associations (PA`s). During sampling the age, sex, breed, coat color and clinical signs were recorded. The required sample size was determined using the procedure described by Thrusfield [14] using 50\% expected prevalence of bovine Trypanosomas in the area and 5\% desired absolute precision and at $95 \%$ confident level. Accordingly, the total sample was determined to be 384 . Classification of the body condition of animal was made by previously described method [15] with scale ranging from 1 (emaciated) to 5 (obese). The age of the animals was grouped as young (1-3 years) and adults ( $\geq 3$ years) according to method followed by Bitew et al. [16].

\section{Parasitological study}

Packed Cell Volume (PCV) determination: Blood samples were collected by puncturing the ear vein with a lancet which was then transferred into a heparinized capillary tubes. Using appropriate procedure in the laboratory the tubes were centrifuged at 12,000 rpm for 5 minute. The centrifuged capillary blood was then red with a haematocrit reader and the reading was recorded in percentage. Animals with PCV $\leq 24 \%$ were considered to be anaemic [17].

Buffy coat technique: The buffy coat was recovered by centrifugation of the blood collected in heparinized microhaematocrit capillary tubes at 12,000 rpm for 5 minute. Since Trypanosomas are found in the Buffy coat layer, the capillary tube was cut $1 \mathrm{~mm}$ below and $3 \mathrm{~mm}$ above the Buffy coat. The Buffy coat was then placed onto a glass slide, and covered with cover slip and was examined for movement of parasite under $\mathrm{x} 40$ objective and $\mathrm{x} 10$ eye piece [18]. Identification of the Trypanosoma species was done based on morphological descriptions as well as movement in wet film preparations [19].

Thin blood smear: A small drop of blood collected using a micro hematocrit capillary tube was placed on a glass slide, air dried and fixed in methyl alcohol for 2 minute and later it was stained with Giemsa stain (1:10 solution) for 30 minute. The excess stain was washed with distilled water and the slide was air dried and examined under the microscope (x100) oil immersion objective lens [20].

Data analysis: The data collected was entered in MS-Excel spreadsheets and hematological data was analyzed using statistical packages for social sciences (SPSS) version 20 software program. The association between prevalence of Trypanosoma infection and risk factors such as age, sex, breed, body conditions and coat color of animals was done using Pearson's chi-square $\left(\chi^{2}\right)$. Statistical significance was held at $\mathrm{P}$-values less than 0.05 in all analysis.

\section{Results}

\section{Parasitological finding}

The current study on vector born trypanosomosis in Dembecha of west Amhara region revealed an overall prevalence of 8.6\% (33/384). The result of the presents study was lower than the finding of previous reports including 14.2\% in Arbaminch [21], 23.36\% [22] from Bahir Dar and $14.68 \%$ [23] from Abay Basin, in Northwest Ethiopia respectively. But the present finding was higher than the prevalence of 2.66\% [24] and $2.10 \%$ [25] reported from West Tigray from North Ethiopia and West Gojam from Northwest Ethiopia respectively. It was also observed that the finding of the present study was in close agreement with the finding of Adane and Gezahegn [26] who reported prevalence of $8.2 \%$ in areas bordering the Blue Nile in Degen, Basoliben and Machakel districts. The discrepancies in the different study areas may be attributed to the geographic area which differs in the population of vectors as well as the various control activities in different areas. For example there were ongoing tse-tse control project activities in 2011 and 2013 northern parts of Ethiopia which has led the prevalence to go down as low as $2.10-2.66 \%[24,25]$.

In the present study out of 384 animals examined 18 (4.7\%) were infected with $T$. congolense and 15 (3.9\%) were infected with $T$. vivax. Hence, $T$. congolense was the predominant species (54.54\%) followed by $T$. vivax $(45.45 \%)$ with no mixed infection at all. Such a high ratio of $T$. congolense may suggest that the major cyclical vectors of Glossina species (G. tachinoide, G. morsitans and other species) are more efficient transmitters of $T$. congolense than T. vivax [27]. The transmission of $T$. congolense is cyclical; it requires the presence of tsetse flies whereas $T$. vivax is more rapidly transmitted via mechanically by biting flies than tsetse fly. The current finding is in agreement with the study conducted by Shimelis et al. [11] (Table 1).

\section{Prevalence of trypanosomiasis with associated risk factors}

In the current study, the association of prevalence with the various risk factors including age, breed, body conditions and coat color were computed (Table 2). Accordingly, the prevalence of Trypanosomosis, although in significant $(\mathrm{p}=0.235)$ it was higher in adults cattle above 3 years old than young ones below 3 years of age. A relatively higher prevalence of Trypanosomosis in adults than young cattle has been previous reported in the country $[21,25]$. The effect of the maternal antibodies which could afford protection to young animals might have contributed to the lower prevalence of Trypanosoma in these animals [28].

With regard to sex of animals, the prevalence of Trypanosomosis was not significantly different (p.0.05) in female and male animals. Similar finds were reported from various parts of the country [2426 ] and this might be due to the management of animals where both male and female are allowed to graze in the field which consequently lead to similar exposure to the biting flies. In animals with poor body condition, the prevalence of Trypanosomosis was significantly higher $(\mathrm{p}=0.000)$ than medium and good body condition cattle apparasitaemic for bovine Trypanosomosis. Similar observations were recorded from studies conducted elsewhere $[21,24,25,29,30]$. This might entail that

\begin{tabular}{|c|c|c|}
\hline Species & No. positive & Prevalence (\%) \\
\hline T. vivax & 15 & 3.9 \\
\hline T. congolense & 18 & 4.7 \\
\hline Total & 33 & 8.6 \\
\hline
\end{tabular}

Table 1: Overall prevalence of Trypanosoma species. 
Citation: Mekonnen D, Eshetu A, Zeryehun T (2017) Prevalence of Bovine Trypanosomosis in Dembecha Woreda Amhara Region, Northwest Ethiopia. J Vet Sci Technol 8: 413. doi: 10.4172/2157-7579.1000413

Page 3 of 4

the disease is responsible to reduce the body condition of animals or trypanosomosis infection occurs in animals with poor body conditions which are likely to have poor immunity against the disease.

The present study revealed that prevalence of Trypanosomosis was significantly different $(\mathrm{P}=0.001)$ among animals with different coat color, where the prevalence is higher in animals with black coat color. The finding agreed to the observation that Glossina species prefers black surfaces as its strongest landing response [31].

\section{Hematological examination}

Cattle with mean PCV values $\leq 24 \%$ were considered anaemic [32]. In the current study, $48.48 \%$ of the parasitemic cattle were anaemic (Table 3). Furthermore, the mean PCV of parasetemic animals (22.94 \pm $2.70 \%)$ was significantly lower $(\mathrm{p}=0.000)$ than the aparastiemic animals $(27.24 \pm 5.02 \%)$ (Table 4). These lowered PCV of parasitemic animals was previously reported in similar studies elsewhere $[21,30,33,34]$. The finding of aparasitemic animals with mean PCV values of $\leq 24 \%$ might be due to the inadequacy of the technique used for detection or delayed recovery of anaemic situation after recent treatment with trypannocidal drugs or factors other than trypanosomosis such as compound effects of poor nutrition and blood feeding helminth infections such as haemonchosis and bunostomosis $[35,36]$.

\section{Conclusion}

Trypanosomiasis is a serious, fatal disease of all domestic and wild animals including human beings. The prevalence of trypanosomiasis in cattle in the present study was $8.6 \%$, and the infection was due to T. congolense and T. vivax. Although the prevalence seems low, owing to the economic importance of the disease serious attention should be given to reduce the prevalence and bring the disease under control.

\section{Acknowledgements}

The authors would like to thank the Bahir Dar Regional Laboratory for the provision of laboratory materials and consumables. More over all the animal owners involved in the study are duly acknowledged for their unreserved willingness and cooperation.

\begin{tabular}{|c|c|c|c|c|c|}
\hline Risk factor & & Total examined & No. positive & Prevalence & $X^{2}$ (p-value) \\
\hline \multicolumn{6}{|l|}{ Age } \\
\hline & $\leq 3$ & 63 & 3 & $4.80 \%$ & $1.409(0.235)$ \\
\hline & $>3$ & 321 & 30 & $9.30 \%$ & \\
\hline \multicolumn{6}{|l|}{ Sex } \\
\hline & Male & 245 & 19 & $7.80 \%$ & $0.606(0.436)$ \\
\hline & Female & 139 & 14 & $10.10 \%$ & \\
\hline \multicolumn{6}{|c|}{ Body condition } \\
\hline & Poor & 88 & 22 & $25 \%$ & $39.46(0.000)$ \\
\hline & Medium & 284 & 10 & $3.50 \%$ & \\
\hline & Good & 12 & 1 & $8.30 \%$ & \\
\hline \multicolumn{6}{|l|}{ Coat color } \\
\hline & Black & 112 & 19 & $17 \%$ & $14.134(0.001)$ \\
\hline & Red & 207 & 11 & $5.30 \%$ & \\
\hline & White & 65 & 3 & $4.60 \%$ & \\
\hline
\end{tabular}

Table 2: Prevalence of Trypanosoma species based on coat color.

\begin{tabular}{|c|c|c|c|}
\hline PCV & No Examined & No. Infected (\%) & Prevalence (\%) \\
\hline Anaemic $(\mathrm{PCV} \leq 24)$ & 292 & $16(48.48 \%)$ & 5.47 \\
\hline Normal (PCV>24) & 92 & $17(51.51)$ & 18.4 \\
\hline Total & 384 & $33(100)$ & -8.6 \\
\hline
\end{tabular}

Table 3: Prevalence of bovine Trypanosomosis based on PCV value.

\begin{tabular}{|l|l|l|l|}
\hline Infection status & No of animals & Mean PCV & t-test \\
\cline { 2 - 4 } & 33 & $22.94 \pm 2.70$ & 4.86 \\
\hline Parasitemic & 351 & $27.24 \pm 5.02$ & 0 \\
\hline Aparasitemic & 351 & (Mean \pm SD) & \\
\hline
\end{tabular}

Table 4: Mean PCV value of parasitemic and aparasitemic animal in cattle. 
Citation: Mekonnen D, Eshetu A, Zeryehun T (2017) Prevalence of Bovine Trypanosomosis in Dembecha Woreda Amhara Region, Northwest Ethiopia. J Vet Sci Technol 8: 413. doi: 10.4172/2157-7579.1000413

\section{References}

1. Aulak, GS, Singla LD, Singh J (2005) Bovine trypanosomosis due to Trypanosoma evansi: Clinical, haematobiochemical and therapeutic studies. In: New Horizons in Animal Sciences, Sobti RC and Sharma VL (eds), Vishal Publishing and Co., Jalandhar, pp: 137-144

2. Sharma A, Singla LD, Tuli A, Kaur P, Bal MS (2015) Detection and assessment of risk factors associated with natural concurrent infection of Trypanosoma evansi and Anaplasma marginale in dairy animals by duplex PCR in eastern Punjab. Trop Ani Helth Prod 47: 251-257.

3. Slingenbergh J (1992) Tsetse control and agricultural development in Ethiopia World Ani Rev 70: 30-36.

4. Admasu B (2002) Welcome address; Animal health and poverty reduction strategies. In: Prov. 16th Animal Conference of Ethiopia the Ethiopia Veterinary Association (EVA), held 56, pp: 117-137

5. Uilenberg G (1998) A field guide for diagnosis treatment and prevention of African animals trypanosomosis. FAO, Rome, pp: 43-89.

6. Stephen LE (1986) Trypanosomosis; a veterinary prospect. Pergamma Press, UK, p: 551.

7. MOA (Ministry of agriculture) (1995) Federal democratic republic of this ruminant livestock development strategy, Ethiopia. p: 28.

8. Murray M, Gray AR (1986) The current situation on animal trypanosomosis in Africa. Preventive Veterinary Medicine 2: 23-30.

9. Dehaan C, Bekure S (1999) Animal health service in Sub-Saharan Africa, initia experience with new approaches. Washington DC, World Bank

10. Cherenet T, Sani RA, Speybroeck N, Panandam JM, Nadzr S (2004) Seasonal prevalence of bovine trypanosomosis in tsetse infected zone and tsetse free zone of Amhara region, North West Ethiopia. J Vet Res 71: 307-314.

11. Shimelis D, Aran KS, Getachew A (2005) Epidemiology of tsetse transmitte trypanosomosis in Abay (Blue Nile) basin of North West Ethiopia. In: proceedings of the $28^{\text {th }}$ meeting of the International Scientific Council for Trypanosomosis.

12. Sinishaw A (2004) Prevalence of trypanomiasis of cattle in three Woreda of Amhara Region. MSc Thesis FVM, AAU, Debre Zeit, Ethiopia.

13. Amhara Regional Agriculture and Rural Development Office (ARARDO) (2010) Woreda livestock palpation data for Debre Elias, Dembecha and Jabitehenan of Amhara Regional Agriculture and Rural Development Office.

14. Thrusfield M (2005) Veterinary Epidemiology. 3rd edn. Blackwell Science Ltd UK, pp: 233-250.

15. Nicholson MJ, Butterworth MH (1986) A guide to condition scoring of zebu cattle. ILCA, Addis Ababa, Ethiopia.

16. Bitew M, Amedie Y, Abebe A, Tolosa T (2011) Prevalence of bovine Trypanosomosis in selected areas of Jabi Tehenan district. West Gojam of Amhara regional state, Northwestern Ethiopia. Afr J Agri Res 6: 140-144.

17. Murray M, Murray PK, Mclntyre WIM (1977) An improved parasitological technique for the diagnosis of African trypanosomisis. Transaction Royal Soc Trop Med Hyg 71: 325-326

18. Paris J, Murray M, Mcodimba F (1982) A comparative evaluation of the parasitological technique currently available for the diagnosis of African Trypanosomosis in cattle, Act Trop 39: 307-316.
19. Woo PTK (1996) The hematological centrifugation technique for the detection of Trypanosomas. Canadian J 47: 921-923.

20. OIE 2008 Trypanosomosis (tsetse-transmitted): Terrestrial Manual. Office International des. Epizooties (OIE), Paris, France.

21. Abraham Z, Tesfaheywet Z (2012) Prevalence of Bovine Trypanosomosis in Selected District of Arba Minch, Snnpr, Southern Ethiopia. Global Vet 8: 168-173.

22. Solomon WM (2003) Amhara project plan and estimate on survey of tsetse and trypanosomosis of domestic animal in Amhara region, Bahir Dar, Ethiopia, p: 5.

23. Shimelis D (2004) Epidemiology of bovine trypanosomosis in the Abay basin area of North West Ethiopia. MSc Thesis, Addis Ababa, FVM, Debre Zeit.

24. Abebayehu T, Berhanu M, Rahmeto R, Solomon M (2011) Mechanically transmitted Bovine Trypanosomosis in Tselamity wereda, Western Tigray, Northern Ethiopia. J Agri 6: 10-13.

25. Ayana M, Tesfaheywet Z, Getnet F (2012) A cross-sectional study on the prevalence of bovine Trypanosomosis in Amhara region, Northwest Ethiopia. Lives Res Rural Develop 24: 1-8.

26. Adane M, Gezahagne M (2001) Bovine trypanosomosis in three districts of East Gojam Zone boardering the Blue Nile River in Ethiopia. J Infect Dev Countries 1: 131-325.

27. Langridger WP (1976) Tsetse and trypanosomosis survey of Ethiopia. Ministry of oversee Department, UK, pp: 1-40.

28. Fimmen HO, Mehlitz D, Horchiner F, Korb E (1992) Colostral antibodies and Trypanosoma congolense infection in calves. Trypanotolerance research application. GTZ, Germany 116, pp: 173-187.

29. Mussa A (2002) Prevalence of Bovine Trypanosomosis in Goro wereda Southwest Ethiopia. DVM Thesis, FVM, AAU, Debre Zeit, Ethiopia.

30. Nigatu SD (2004) Epidemiology of bovine trypanosomosis in the Abbay Basin areas of Northwest Ethiopia. MSc Thesis, FVM, AAU, Debre Zeit, Ethiopia.

31. Leak SGA (1999) Tsetse biology and ecology. Their role in the epidemiology and control of trypanosomosis. Wallingford, UK: CABI publishing in association with the ILRI, pp: 152-210.

32. Van den Bossche P, Shumba W, Makhambera P (2000) The distribution and epidemiology of bovine trypanosomosis in Malawi. Vet Parasitol 88: 163-176.

33. Dinka H, Abebe G (2005) Small ruminant trypanosomosis in the southwest of Ethiopia. Small Rum Res 57: 239-243.

34. Sinishaw A, Abebe G, Desquesnes M, Yoni W (2006) Biting flies and Trypanosoma vivax infections in three highland districts bordering Lake Tana Ethiopia. Vet Parasitol 142: 35-46.

35. Afework YS, Clausen PH, Abebe G, Tilahun G, Mehlitz D (2000) A prevalence of multiple drug-resistant $\mathrm{T}$. congolense population in village cattle of Mekele district, North-West Ethiopia. Act Trop 76: 231-138.

36. Van den Bossche P, Rowlands GJ (2001) The relationship between the parasitological prevalence of trypanosomal infection in cattle and herd average packed cell volume. Act Trop 78: 163-170. 